\title{
Cephalopod prey of the wandering albatross Diomedea exulans
}

\author{
P. G. Rodhouse ${ }^{1}$, M. R. Clarke $^{2}$ and A. W. A. Murray ${ }^{1}$ \\ 1 British Antarctic Survey, Natural Environment Research Council; High Cross, Madingley Road, Cambridge CB3 OET, England \\ 2 The Laboratory, Marine Biological Association; Citadel Hill, Plymouth PL1 2PB, Devon, England
}

\begin{abstract}
Cephalopod beaks from the stomach contents of "wandering albatross" (Diomedea exulans L.) chicks from Bird Island, South Georgia, were sampled between May and September in 1983 and 1984. Lower beaks were identified and measured, and allometric data were used to calculate mantle length and biomass of the species consumed. A total of 3421 lower beaks were examined, representing 35 species in the 1983 sample and 45 species in the 1984 sample. Eight of the twenty families contributed over $95 \%$ of the biomass. In 1984 there were less Onychoteuthidae and more Ommastrephidae than in 1983 and a decrease in the number of species known to occur south of the Antarctic Polar Front. There was a difference in the size-frequency distribution of the cephalopod diet in the two years; in 1984 there was a higher frequency of intermediate-sized specimens, reflecting the greater importance of ommastrephids, especially Illex sp. The energy content of cephalopods in 1984 may have been greater than in 1983. Serial sampling of cephalopod beaks during the austral winter did not reveal evidence of growth. By the age of $200 \mathrm{~d}$, wandering albatross chicks have consumed a total of approximately $100 \mathrm{~kg}$ wet weight of cephalopods each.
\end{abstract}

\section{Introduction}

The "wandering albatross", Diomedea exulans, has long been recognised as a predator of cephalopods in the Southern Ocean (Matthews, 1929). Adults and chicks accumulate considerable numbers of indigestible cephalopod beaks in the stomach, which can be sampled by inducing the bird to regurgitate. Recent advances in the identification of cephalopod beaks (Clarke, 1986) enable much information to be derived from these samples.

The first study of cephalopods in the diet of wandering albatrosses, based on seven samples ( 281 beaks), was made by Imber and Russ (1975). A more detailed study of 18 samples (532 beaks) was made by Clarke et al. (1981). Here, we describe serial collections of cephalopod material involving 3421 lower beaks from 79 samples taken from chicks at the nest on Bird Island, South Georgia, during two breeding seasons, 1983 and 1984. Wandering albatrosses raise their chicks during the Antarctic winter (Tickell, 1968). These collections were separated by an Antarctic summer season, which was marked by a significant decline in standing-crop biomass of krill (Euphausia super$b a$ ) in the vicinity of South Georgia (Heywood et al., 1985). This was associated with reduced breeding success in the Macaroni penguins Eudyptes chrysolophus, the gentoo Penguins Pygoscelis papua, the black-browed albatrosses Diomedea melanophris, and, to a lesser extent, the greyheaded albatrosses, D. chrysostoma (Croxall et al., in press). The breeding success of the wandering albatrosses was unaffected, but it was notable that the proportion of cephalopods in the diet decreased from $39.5 \%$ in 1983 to $29.7 \%$ in 1984; the difference being compensated for by fish in the second year (Croxall and Prince, personal communication).

\section{Materials and methods}

The stomach contents of wandering albatross (Diomedea exulans L.) chicks at the breeding colony on Bird Island, South Georgia were sampled at approximately monthly intervals between May and September 1983 and 1984. Samples were taken by inducing the chicks to regurgitate immediately after being fed by a parent bird. No chick was sampled more than once. All cephalopod beaks were removed from the samples and preserved in formalin. Lower beaks were identified by reference to features given by Clarke (1986).

Lower rostral length (LRL) of squid beaks and lower hood length (LHL) of octopodid beaks were measured to $0.1 \mathrm{~mm}$ with vernier calipers. Allometric equations given 
by Clarke (1986) were used to relate LRL or LHL to original wet body weight and mantle length of the cephalopod. Where appropriate equations were not available, these were derived from new material (Rodhouse, unpublished data) or estimates were made from equations for closely related species or for species with similar morphologies.

\section{Results}

Taxonomic analysis of cephalopod prey

A total of 3421 lower beaks were identified and measured from the regurgitations of Diomedea exulans chicks, 1474 from the 1983 sample and 1947 from the 1984 sample. Numbers of beaks from each cephalopod species and wet weight biomass represented by these beaks for each year are given in Table 1.

Identified cephalopod species are given here together with their contribution to diet as a percentage of total numbers and estimated percentage contribution to total cephalopod biomass. Where the contribution of a species to total numbers or weight is $<1 \%$, data for both years are combined to derive size-frequency peaks.

\section{Order Teuthoidea}

Family Loliginidae

\section{Loligo sp}

Present in 1983 and $1984 ;<1 \%$ by numbers and weight; LRL: 1.8 to $3.0 \mathrm{~mm}$, peak at 2.0 to $2.5 \mathrm{~mm}$.

\section{Family Gonatidae}

Gonatus antarcticus (Lonnberg, 1898)

In 1983 and 1984 this species contributed 2.6 and $2.4 \%$ by numbers and 1.2 and $1.0 \%$ by weight, respectively; LRL: 4.9 to $8.1 \mathrm{~mm}$, peak at 6.0 to $7.0 \mathrm{~mm}$ in 1983 and at 5.5 to $6.0 \mathrm{~mm}$ in 1984 (Fig. 1). Clarke et al. (1981) found two peaks in LRL frequency within the same size range of Gonatus antarcticus lower beaks from wandering albatrosses. Beaks from the smaller group were ascribed to a second, unknown species by these authors. Here, we found no evidence of the smaller peak within this size range and so have provisionally assigned all Gonatus beaks to $G$. antarcticus.

Family Enoploteuthidae

Ancistrocheirus lesueuri (d'Orbigny, 1839)

Present in 1983 and $1984 ;<1 \%$ by numbers and weight; LRL: 6.2 to $8.2 \mathrm{~mm}$, peak at 7.5 to $8.0 \mathrm{~mm}$.
Table 1. Diomedea exulans. Numbers of identified cephalopod beaks in regurgitations of chicks and wet weight biomass represented by these beaks

\begin{tabular}{|c|c|c|c|c|}
\hline \multirow[t]{2}{*}{ Family and species } & \multicolumn{2}{|c|}{ Numbers } & \multicolumn{2}{|c|}{ Biomass (g) } \\
\hline & 1983 & 1984 & 1983 & 1984 \\
\hline \multicolumn{5}{|l|}{ Loliginidae } \\
\hline Loligosp. & 3 & 8 & 453 & 1097 \\
\hline \multicolumn{5}{|l|}{ Gonatidae } \\
\hline Gonatus antarcticus & 38 & 47 & 10726 & 10893 \\
\hline \multicolumn{5}{|l|}{ Enoploteuthidae } \\
\hline $\begin{array}{l}\text { Ancistrocheirus lesueuri } \\
\text { Octopoteuthidae }\end{array}$ & 2 & 3 & 2359 & 2960 \\
\hline Octopoteuthis rugosa & 1 & 0 & 214 & 0 \\
\hline Taningia danae & 8 & 10 & 26334 & 25042 \\
\hline \multicolumn{5}{|l|}{ Onychoteuthidae } \\
\hline Kondakovia longimana & 192 & 151 & 555209 & 617961 \\
\hline Morotheuthis knipovitchi & 47 & 14 & 36817 & 9482 \\
\hline Morotheuthis ingens & 10 & 15 & 35409 & 44664 \\
\hline Morotheuthis robsoni & 2 & 6 & 2803 & 8199 \\
\hline Onychoteuthis banksi & 3 & 1 & 563 & 2034 \\
\hline \multicolumn{5}{|l|}{ Pholidoteuthidae } \\
\hline Pholidoteuthis boschmai & 0 & 1 & 0 & 44 \\
\hline \multicolumn{5}{|l|}{ Batoteuthidae } \\
\hline Batoteuthis skolops & 36 & 51 & 1073 & 1356 \\
\hline \multicolumn{5}{|l|}{ Histioteuthidae } \\
\hline Histiotheuthis sp. A & 63 & 10 & 8926 & 1009 \\
\hline Histiotheuthis eltaninae & 247 & 230 & 20090 & 19676 \\
\hline Histiotheuthis atlantica & 62 & 113 & 13683 & 18720 \\
\hline \multicolumn{5}{|l|}{ Psychroteuthidae } \\
\hline Psychroteuthis glacialis & 52 & 15 & 5097 & 1786 \\
\hline ? Large Psychroteuthis & 6 & 7 & 4524 & 3960 \\
\hline \multicolumn{5}{|l|}{ Neoteuthidae } \\
\hline Alluroteuthis antarcticus & 88 & 76 & 35425 & 28939 \\
\hline Architeuthidae & & & & \\
\hline Architeuthis sp. & 0 & 1 & 0 & 23227 \\
\hline Ommastrephidae & & & & \\
\hline Illex sp. & 165 & 648 & 53137 & 208781 \\
\hline Martialia hyadesi & 45 & 75 & 15917 & 25738 \\
\hline Chiroteuthidae & & & & \\
\hline Chiroteuthis imperator & 1 & 1 & 104 & 67 \\
\hline Chiroteuthis sp. (large) & 11 & 3 & 436 & 247 \\
\hline Chiroteuthis sp. (small) & 0 & 2 & 0 & 80 \\
\hline Chiroteuthis sp. A & 6 & 1 & 527 & 57 \\
\hline Lepidoteuthidae & & & & \\
\hline Lepidoteuthis grimaldii & 3 & 2 & 4699 & 6655 \\
\hline Mastigoteuthidae & & & & \\
\hline Mastigoteuthis sp. (large) & 35 & 19 & 9581 & 4674 \\
\hline Mastigoteuthis sp. (small) & 2 & 1 & 248 & 139 \\
\hline Mastigoteuthis sp. A & 0 & 4 & 0 & 879 \\
\hline Cycloteuthidae & & & & \\
\hline Discoteuthis sp. (large) & 3 & 5 & 1046 & 1515 \\
\hline Discoteuthis sp. (small) & 5 & 2 & 615 & 249 \\
\hline Cranchiidae & & & & \\
\hline Egea inermis & 0 & 1 & 0 & 78 \\
\hline Galiteuthis glacialis & 273 & 358 & 2440 & 30735 \\
\hline Galiteuthis sp. & 1 & 3 & 60 & 172 \\
\hline Helicocranchia sp. & 2 & 1 & 58 & 28 \\
\hline Megalocranchia sp. & 0 & 1 & 0 & 280 \\
\hline Mesonychoteuthis hamiltoni & 0 & 3 & 0 & 628 \\
\hline Taonius pavo & 13 & 5 & 3775 & 1483 \\
\hline Taonius sp. & 24 & 16 & 6215 & 4230 \\
\hline Taonius sp B. (small) & 0 & 2 & 0 & 278 \\
\hline Taonius sp B. (southern) & 0 & 8 & 0 & 2451 \\
\hline Teuthowenia sp. & 2 & 3 & 655 & 816 \\
\hline Alloposidae & & & & \\
\hline Alloposus mollis & 21 & 15 & 11555 & 8201 \\
\hline Octopodidae & & & & \\
\hline Large octopodid & 0 & 5 & 0 & 11144 \\
\hline Small octopodid & 2 & 1 & 241 & 1125 \\
\hline Vampyromorphidae & & & & \\
\hline Vampyroteuthis infernalis & 0 & 1 & 0 & 77 \\
\hline
\end{tabular}



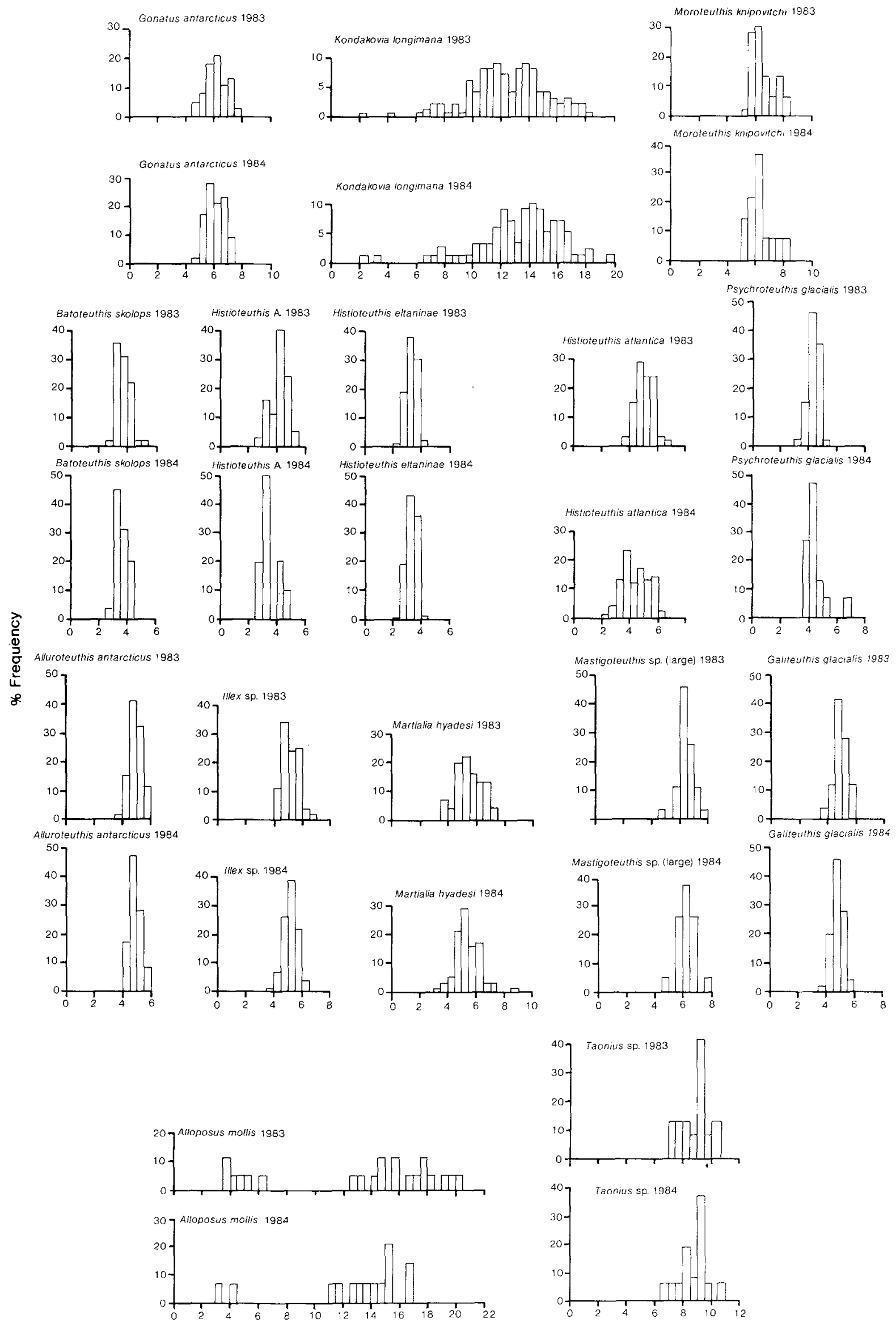

Lower rostral length or hood length $(\mathrm{mm})$

Fig. 1. Diomedea exulans chicks. Frequency distributions of lower rostral length and hood length for major cephalopod species in diet in 1983 and 1984 
Family Octopoteuthidae

Octopoteuthis rugosa Clarke, 1980

One specimen in $1983 ;<1 \%$ by numbers and weight; LRL: $9.5 \mathrm{~mm}$.

Taningia danae Joubin, 1923

Present in 1983 and $1984 ;<1 \%$ by numbers but 3.0 and $2.2 \%$ by weight, respectively; LRL: 9.0 to $15.7 \mathrm{~mm}$, peak at 13.0 to $13.5 \mathrm{~mm}$.

Family Onychoteuthidae

\section{Kondakovia longimana Filippova, 1972}

In 1983 and 1984 this species contributed 13.0 and $7.8 \%$ by numbers and 62.2 and $54.6 \%$ by weight, respectively; LRL: 2.3 to $20.0 \mathrm{~mm}$, peak at 11.5 to $12.0 \mathrm{~mm}$ in 1983 and at 14.0 to $14.5 \mathrm{~mm}$ in 1984; evidence of a class of much smaller squids in each year (Fig. 1).

\section{Moroteuthis knipovitchi Filippova, 1972}

In 1983 and 1984 this species contributed 3.2 and $0.7 \%$ by numbers and 4.1 and $0.8 \%$ by weight, respectively; LRL: 5.2 to $15.3 \mathrm{~mm}$, peak at 6.0 to $6.5 \mathrm{~mm}$ in 1983 and 1984 (Fig. 1).

\section{Moroteuthis ingens (Smith, 1881)}

Present in 1983 and $1984 ;<1 \%$ by numbers but $4.0 \%$ each year by weight; LRL: 9.0 to $13.2 \mathrm{~mm}$, peak at 10.0 to $10.5 \mathrm{~mm}$.

\section{Moroteuthis robsoni (Adam, 1962)}

Present in 1983 and $1984 ;<1 \%$ by numbers and weight; LRL: 7.6 to $8.5 \mathrm{~mm}$, peak at 7.5 to $8.0 \mathrm{~mm}$.

Onychoteuthis banksi (Leach, 1817)

Present in 1983 and $1984 ;<1 \%$ by numbers and weight; LRL: 3.2 to $6.7 \mathrm{~mm}$, peak at 3.5 to $4.0 \mathrm{~mm}$.

Family Pholidoteuthidae

Pholidoteuthis boschmai Adam, 1950

One specimen in $1984,<1 \%$ by numbers and weight; LRL: $2.7 \mathrm{~mm}$.
Family Batoteuthidae

Batoteuthis skolops Young and Roper, 1968

In 1983 and 1984 this species contributed 2.4 and $2.6 \%$ by numbers, respectively, but $<1.0 \%$ by weight; LRL: 2.9 to $5.4 \mathrm{~mm}$, peak at 3.0 to $3.5 \mathrm{~mm}$ in 1983 and 1984 (Fig. 1).

Family Histioteuthidae

\section{Histioteuthis sp. A}

In 1983 and 1984, beaks of Histioteuthis Type "A" (Clarke, 1986) contributed 4.3 and $0.5 \%$ by numbers and 1.0 and $0.1 \%$ by weight, respectively; LRL: 2.9 to $5.3 \mathrm{~mm}$, peak at 4.0 to $4.5 \mathrm{~mm}$ in 1983 and at 3.0 to $3.5 \mathrm{~mm}$ in 1984 (Fig. 1). These peaks possibly represent different species. There is evidence of a smaller peak in 1983 which may correspond with the 1984 peak.

Histioteuthis eltaninae N. Voss, 1969

Beaks of Histioteuthis Type "B" (Clarke, 1986) were present in 1983 and 1984. There appear to be two distinct size groups. On this basis, and the stage of darkening, the smaller group was assigned to $H$. eltaninae and the larger group to $H$. atlantica (see Clarke et al., 1981).

In 1983 and 1984, Histioteuthis eltaninae contributed 16.8 and $11.8 \%$ by numbers and 2.3 and $1.7 \%$ by weight, respectively; LRL: 2.5 to $4.5 \mathrm{~mm}$, peak at 3.0 to $3.5 \mathrm{~mm}$ in 1983 and 1984 (Fig. 1).

Histioteuthis atlantica Hoyle, 1885

In 1983 and 1984 this species contributed 4.2 and $5.8 \%$ by numbers and 1.5 and $1.6 \%$ by weight, respectively; LRL: 2.5 to $6.7 \mathrm{~mm}$, peak at 4.5 to $5.0 \mathrm{~mm}$ in 1983 and at 3.5 to $4.0 \mathrm{~mm}$ in 1984 (Fig. 1).

Family Psychroteuthidae

Psychroteuthis glacialis Thiele, 1921

In 1983 and 1984 this species contributed 3.5 and $0.8 \%$ by numbers but $<1.0 \%$ by weight; LRL: 3.5 to $6.6 \mathrm{~mm}$, peak at 4.0 to $4.5 \mathrm{~mm}$ in 1983 and 1984 (Fig. 1).

\section{? Large Psychroteuthis}

Beaks assigned to this species come from an unknown squid which is possibly not related to the Psychroteuthidae (Clarke, 1986). It was present in 1983 and 1984; <1\% by numbers and weight; LRL: 4.2 to $7.9 \mathrm{~mm}$, peak at 7.0 to $7.5 \mathrm{~mm}$. 
Family Neoteuthidae

Alluroteuihis antarcticus Odhner, 1923

In 1983 and 1984 this species contributed 6.0 and $3.9 \%$ by numbers and 4.0 and $2.6 \%$ by weight, respectively; LRL: 4.0 to $6.0 \mathrm{~mm}$, peak at 4.5 to $5.0 \mathrm{~mm}$ in 1983 and 1984 (Fig. 1).

Family Architeuthidae

Architeuthis sp.

One specimen present in $1984 ;<1 \%$ by numbers and weight; LRL: $13.3 \mathrm{~mm}$.

Family Ommastrephidae

Illex sp.

This is probably Illex argentimus (Castellanos, 1960). In 1983 and 1984 it contributed 11.2 and $33.3 \%$ by numbers and 6.0 and $18.4 \%$ by weight, respectively; LRL: 3.3 to $8.2 \mathrm{~mm}$, peak at 4.5 to $5.0 \mathrm{~mm}$ in 1983 and at 5.0 to $5.5 \mathrm{~mm}$ 1984 (Fig. 1).

\section{Martialia hyadesi Rochbrune and Mabille, 1889}

In 1983 and 1984 this species contributed 3.1 and $3.8 \%$ by numbers and 1.8 and $2.3 \%$ by weight, respectively; LRL: 3.5 to $8.8 \mathrm{~mm}$, peak at 5.0 to $5.5 \mathrm{~mm}$ in 1983 and 1984 (Fig. 1).

Family Chiroteuthidae

Chiroteuthis imperator Chun, 1910

One specimen present in 1983 and $1984 ;<1 \%$ by numbers and weight; LRL: 6.1 and $5.2 \mathrm{~mm}$, respectively.

\section{Chiroteuthis sp. (large)}

Present in 1983 and 1984 ; < $1 \%$ by numbers and weight; LRL: 3.4 to $6.8 \mathrm{~mm}$, peak at 3.0 to $3.5 \mathrm{~mm}$.

\section{Chiroteuthis sp. (small)}

Two specimens present in $1984 ;<1 \%$ by numbers and weight; LRL: 2.9 and $4.9 \mathrm{~mm}$.

\section{Chiroteuthis sp. A}

Present in 1983 and $1984 ;<1 \%$ by numbers and weight; LRL: 4.3 to $8.2 \mathrm{~mm}$, peak at 4.5 to $5.0 \mathrm{~mm}$.
Family Lepidoteuthidae

Lepidoteuthis grimaldii Joubin, 1895

Present in 1983 and $1984 ;<1 \%$ by numbers and weight; LRL: 9.1 to $15.8 \mathrm{~mm}$, peak at 7.5 to $8.0 \mathrm{~mm}$.

Family Mastigoteuthidae

Mastigoteuthis sp. (large)

In 1983 and 1984 this species contributed 2.4 and $1.0 \%$ by numbers and 1.0 and $0.4 \%$ by weight, respectively; LRL: 4.8 to $7.9 \mathrm{~mm}$, peak at 6.0 to $6.5 \mathrm{~mm}$ in 1983 and 1984 (Fig. 1).

Mastigoteuthis sp. (small)

Present in 1983 and 1984 ; <1\% by numbers and weight; LRL: 5.0 to $5.2 \mathrm{~mm}$, peak at $5.0 \mathrm{~mm}$.

\section{Mastigoteuthis sp. A}

Four specimens present in $1984 ;<1 \%$ by numbers and weight; LRL: 5.9 to $6.2 \mathrm{~mm}$, peak at 6.0 to $6.2 \mathrm{~mm}$.

Family Cycloteuthidae

Discoteuthis sp.

Present in 1983 and 1984 ; < $1 \%$ by numbers and weight; LRL: 6.7 to $7.8 \mathrm{~mm}$, peak at 7.0 to $7.5 \mathrm{~mm}$.

Discoteuthis sp. (small)

Present in 1983 and $1984 ;<1 \%$ by numbers and weight; LRL: 4.1 to $4.9 \mathrm{~mm}$, peak at 4.0 to $4.5 \mathrm{~mm}$.

Family Cranchiidae

Egea inermis Joubin, 1933

One specimen present in $1984 ;<1 \%$ by numbers and weight; LRL: $5.1 \mathrm{~mm}$.

Galiteuthis glacialis (Chun, 1906)

In 1983 and 1984 this species contributed 18.5 and $18.4 \%$ by numbers, respectively, and $2.7 \%$ each year by weight; LRL: 3.2 to $6.4 \mathrm{~mm}$, peak at 4.5 to $5.0 \mathrm{~mm}$ in 1983 and 1984 (Fig. 1). 
Galiteuthis sp. (see Clarke, 1986: his Fig. 99 D)

Present in 1983 and $1984 ;<1 \%$ by numbers and weight; LRL: 4.0 to $4.2 \mathrm{~mm}$, peak at 4.0 to $4.2 \mathrm{~mm}$.

Helicocranchia sp.

Present in 1983 and 1984 ; < $1 \%$ by numbers and weight; LRL: 3.0 to $3.5 \mathrm{~mm}$, peak at 3.0 to $3.5 \mathrm{~mm}$.

Megalocranchiasp.

One specimen in $1984 ;<1 \%$ by numbers and weight; LRL: $8.2 \mathrm{~mm}$.

\section{Mesonychteuthis hamiltoni Robson, 1924}

Three specimens in $1984 ;<1 \%$ by numbers and weight; LRL: 5.9 to $10.0 \mathrm{~mm}$.

Taonius pavo (Lesueur, 1821)

Present in 1983 and 1984; <1\% by numbers and weight; LRL: 7.0 to $10.5 \mathrm{~mm}$, peak at 9.0 to $9.5 \mathrm{~mm}$.

\section{Taonius sp.}

In 1983 and 1984 this species contributed 1.6 and $0.8 \%$ by numbers and weight, respectively; LRL: 7.0 to $11.0 \mathrm{~mm}$, peak at 9.0 to $9.5 \mathrm{~mm}$ in 1983 and 1984 (Fig. 1).

\section{Taonius sp. B (small)}

Two specimens in 1984 ; <1\% by numbers and weight; LRL: 6.5 and $6.8 \mathrm{~mm}$, respectively.

Taonius sp. B (southern)

Eight specimens in $1984 ;<1 \%$ by numbers and weight; LRL: 7.9 to $9.9 \mathrm{~mm}$, peak at 9.5 to $10.0 \mathrm{~mm}$.

\section{Teuthowenia sp.}

Present in 1983 and 1984 ; < $1 \%$ by numbers and weight; LRL: 7.0 to $9.0 \mathrm{~mm}$, peak at 8.0 to $8.5 \mathrm{~mm}$.

\section{Order Octopoda}

Family Alloposidae

Alloposus mollis Verrill, 1880

In 1983 and 1984 this species contributed 1.4 and $0.8 \%$ by numbers and 1.3 and $0.7 \%$ by weight, respectively; LHL: 3.5 to $21.0 \mathrm{~mm}$, peaks at 3.5 to $4.0 \mathrm{~mm}$ and 15.5 to $16.0 \mathrm{~mm}$ in 1983 and at 3.0 to $4.5 \mathrm{~mm}$ and 15.0 to $15.5 \mathrm{~mm} 1984$ (Fig. 1).

Octopodidae

In 1984 there were five beaks from large unidentified octopodids; < $1 \%$ by numbers but $1.0 \%$ by weight; LHL: 5.4 to $11.4 \mathrm{~mm}$; no size-frequency peak. In 1983 there was one small octopodid; $<1.0 \%$ by numbers and weight; LHL: $3.8 \mathrm{~mm}$. In 1984 there were two small octopodids; $<1.0 \%$ by numbers and weight; LHL: 4.8 and $5.4 \mathrm{~mm}$.

\section{Order Vampyromorpha}

Family Vampyromorphidae

Vampyroteuthis infernalis Chun, 1903

In 1984 there was one beak from this species; $<1.0 \%$ by numbers and weight; LHL: $7.0 \mathrm{~mm}$.

Contribution to diet of different cephalopod families

Of the twenty cephalopod families represented in the collection (Table 1), eight families contributed $95.6 \%$ of the biomass consumed. The other families each contributed $<1.0 \%$. The percent biomass contributed by the eight most important families in each of the two years is shown in Fig. 2. The relative contribution of each of these eight families was similar in each year except for the Onychoteuthidae and the Ommastrephidae. There was a decrease in importance of the Onychoteuthidae and an increase in the Ommastrephidae in 1984. This was largely due to an increase in the numbers and biomass of Illex sp. and a decrease in the numbers and biomass of Kondakovia longimana and Moroteuthis knipovitchi in 1984 (Table 1 and Fig. 3).

Relative contribution of "Antarctic" and "non-Antarctic" cephalopod species

Although the distribution of cephalopods in the Southern Ocean is poorly known, some measure of the relative importance of "Antarctic" and "non-Antarctic" species was derived by classifying the collection according to known occurrence to the south of the sub-Antarctic Front (SAF) (Fischer and Hureau, 1985; Okutani and Clarke, 1985). 


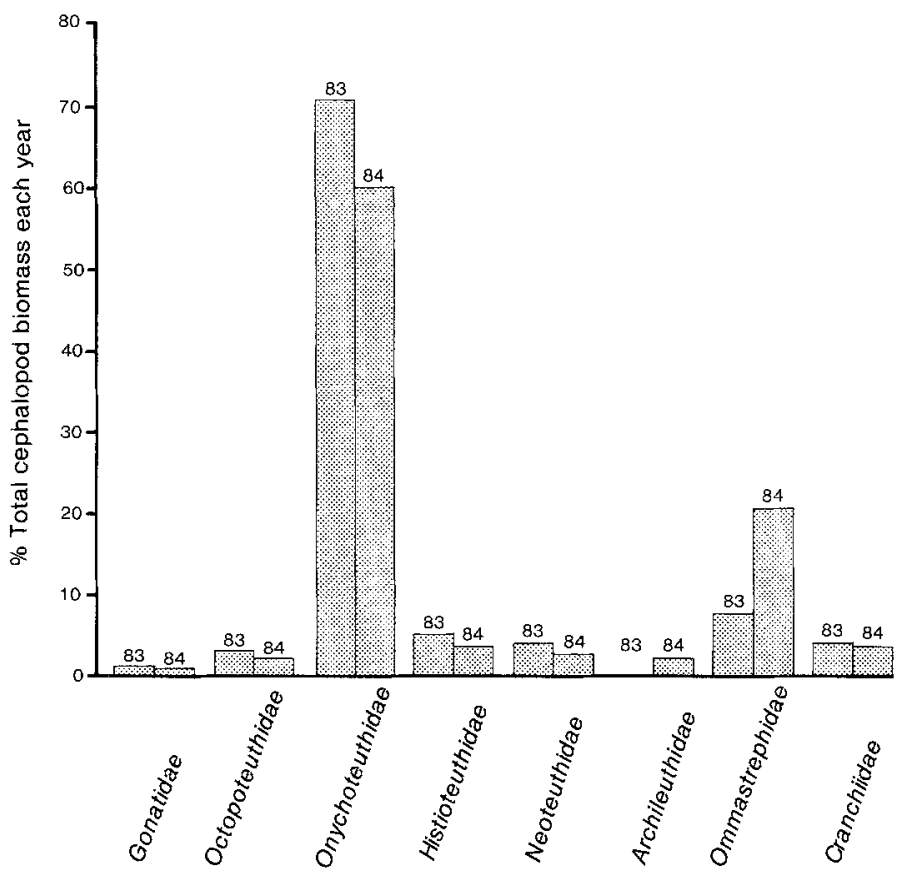

Fig. 2. Diomedea exulans chicks. Relative contribution of each of 8 most important cephalopod families to diet in 1983 and 1984

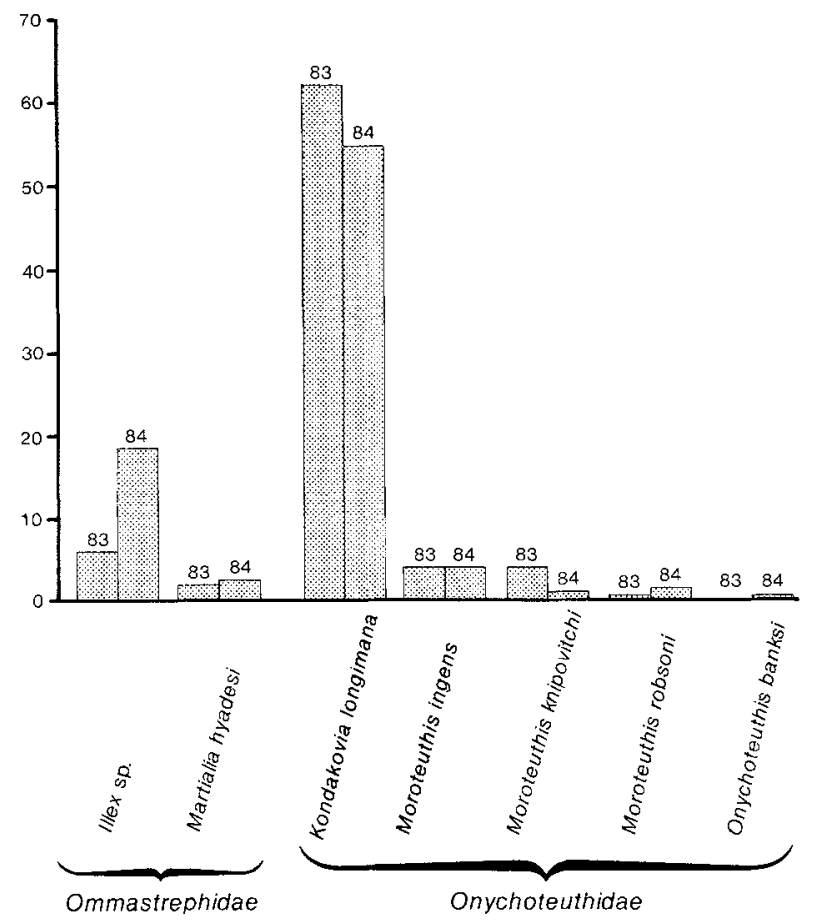

Fig. 3. Diomedea exulans chicks. Relative contribution of ommastrephid and onychoteuthid species to diet in 1983 and 1984

Species defined here as "Antarctic", with a known distribution south of the SAF, are: Gonatus antarcticus, Kondakovia longimana, Moroteuthis knipovitchi, M. ingens, M. robsoni, Batoteuthis skolops, Psychroteuthis glacialis, ? large Psychroteuthis, Martialia hyadesi, Chiroteuthis sp., Mastigoteuthis sp. A, Galiteuthis glacialis and Mesonychteuthis hamiltoni. The relative contribution of "Antarctic" and "non-Antarctic" species is given in Table 2. There

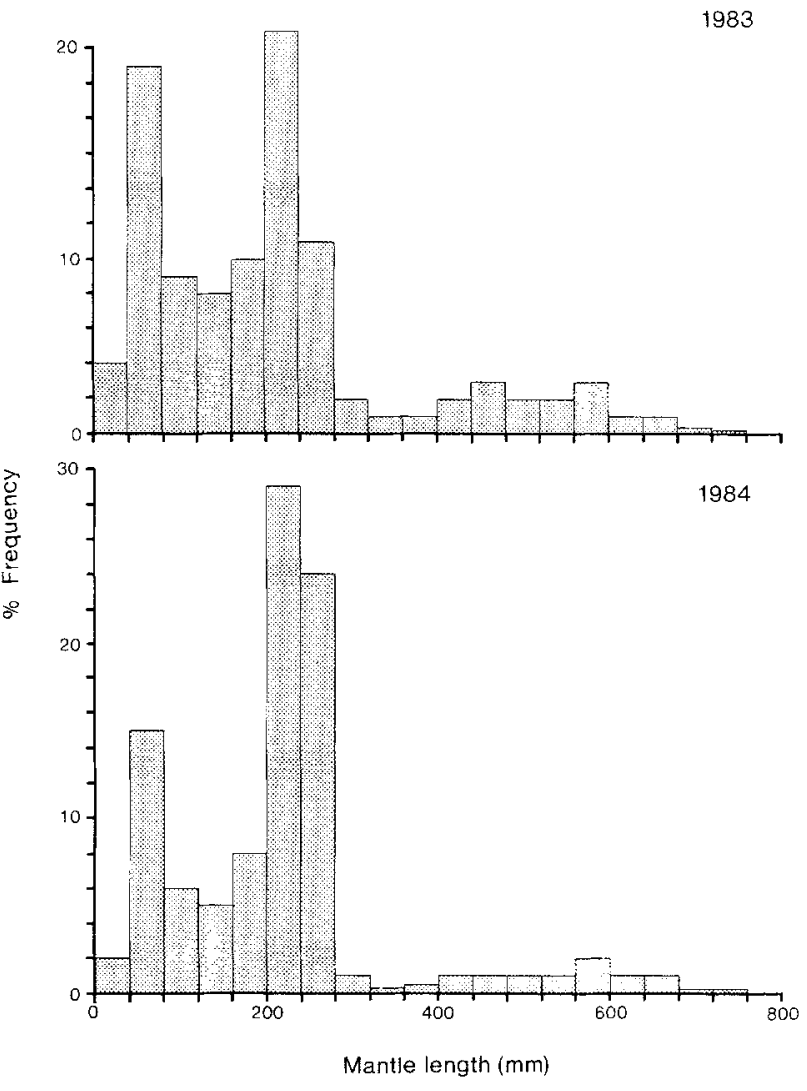

Fig. 4. Diomedea exulans. Pooled data of estimated mantle-length frequency-distributions of all cephalopods from regurgitations of chicks in 1983 and 1984

Table 2. Diomedea exulans chicks. Relative contribution (\%) of "Antarctic" and "non-Antarctic" cephalopods to diet

\begin{tabular}{lll}
\hline Year & "Antarctic" & "non-Antarctic" \\
\hline Numbers & & \\
1983 & 54 & 46 \\
1984 & 42 & 58 \\
Biomass & & \\
1983 & 81 & 19 \\
1984 & 69 & 31 \\
\hline
\end{tabular}

was a marked reduction in the contribution of "Antarctic" species, in terms of species and biomass, to the diet of wandering albatrosses in 1984.

Size-frequency distribution of cephalopod prey

Frequency distributions of estimated mantle lengths, combined for all species in the 1983 and 1984 collections are shown in Fig. 4. The general form of the distribution is very similar in both years, with major peaks at 40 to $80 \mathrm{~mm}, 200$ to $240 \mathrm{~mm}$ and 560 to $600 \mathrm{~mm}$ mantle length. However, it is notable that in 1984 the relative importance of the peaks at each end of the distribution are reduced relative to the major peak at 200 to $240 \mathrm{~mm}$. This reflects the increased number of Illex sp. fed to chicks in 1984. 


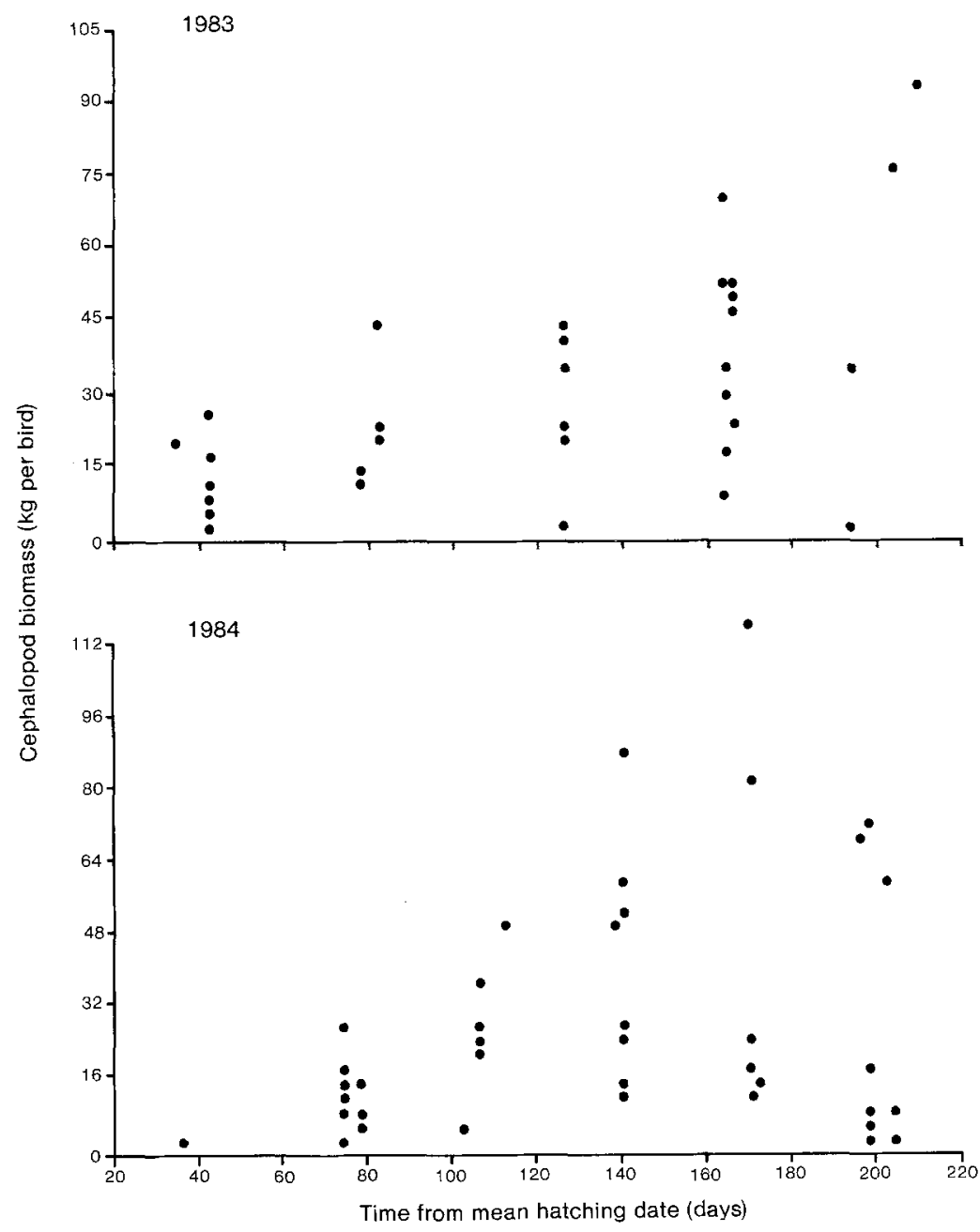

Fig. 5. Diomedea exulans. Wet weight biomass represented by cephalopod beaks regurgitated by chicks, as a function of time after mean hatching date in 1983 and 1984. Data points represent individual chicks
Accumulation of cephalopod beaks

The estimated biomass represented by beaks regurgitated by each chick, as a function of time after mean hatching date, is shown in Fig. 5. Mean hatching dates were 12 March 1983 and 10 March 1984. In both years there was a general increase in biomass during the early months of the life of the chick, but thereafter the data became increasingly variable. This suggests that, as development progresses, cephalopod beaks are lost from the chicks stomach, either in regurgitations or in the faeces, or that it becomes more difficult to recover all cephalopod beaks from the older, larger chicks. Maximum estimates of the biomass of cephalopods consumed by chicks are 70 to $90 \mathrm{~kg}$ in 1983 and 80 to $110 \mathrm{~kg}$ in 1984 . These values will be overestimates to the extent that not all beaks will have come from whole cephalopods, but underestimates by the amount of cephalopods still to be delivered before the chicks fledge at 260 to $280 \mathrm{~d}$ of age and by the number of beaks consumed but not recovered from the chick.

Despite these potential sources of error, it seems possible that chicks ingest up to $100 \mathrm{~kg}$ of cephalopods each during the rearing period. This is not unrealistic because between the end of the brooding period and fledging, chicks receive about 80 meals (Tickell, 1968) of 1 to $2 \mathrm{~kg}$
(Tickell, 1968; Croxall and Prince, unpublished data) of which about $35 \%$ by weight is cephalopods (Croxall and Prince, unpublished data). Thus, the average chick should receive in excess of 30 to $60 \mathrm{~kg}$ of cephalopods during the rearing period.

\section{Cohort analysis}

Four squid species were sufficiently common throughout the sampling periods in both years for cohort analysis of the LRL frequency distributions. These were the "Antarctic" species Kondakovia longimana and Galiteuthis glacialis and the "non-Antarctic" species Illex? argentinus and Histioteuthis eltaninae. There is no evidence of temporal shifts in peaks of these distributions which could be attributed to growth.

Heterogeneity of species-frequency

A two-way contingency table classified by species and year was drawn up to test for heterogeneity of species-frequency between years. The sixteen most common species were allocated separate columns in the table, with the remaining 
thirty species grouped into one column. A log-linear model was fitted to the table as described by Nelder and McCullagh (1983). The residual deviance which is distributed as $\chi^{2}$, indicated that there were considerable changes in relative frequency of species between the two years $(P<0.001)$.

\section{Index of diversity}

The Shannon-Wiener index of diversity (Pielou, 1966) was calculated for each year separately and both years combined. The value for 1983 was 2.619 and for 1984 it was 2.287; for both years combined it was 2.495. Associated values for eveness were $0.731,0.697$ and 0.648 , respectively.

\section{Discussion}

A total of forty-six cephalopod species were identified from beaks in the regurgitations of wandering albatross (Diomedea exulans) chicks, sampled during the austral winter. This is nearly twice as many as recorded by Clarke $e t$ al. (1981) from chicks sampled at the same site, but the present collection was larger and more comprehensive. In common with the earlier study, the large hooked squid Kondakovia longimana dominated the sample in terms of biomass but not in numbers. Most of the species in this study which were not found by Clarke et al. (1981) were only present in small numbers, with the exception of the arrow squids Illex sp. and Martialia hyadesi. These species were sufficiently abundant to make the Ommastrephidae the second most important family in the diet in terms of biomass.

The 1984 sample contained ten more species than the 1983 sample, but the index of diversity decreased slightly. The additional species in 1984 were sufficiently rare as to make very little contribution to the index. Indeed, their presence in the sample caused the calculated measure of eveness (Pielou, 1966) to decrease. Therefore, their occurrence did not increase the degree of uncertainty attached to the specific identity of any randomly selected individual.

Comparison with the data from 1976/1977 (Clarke et al., 1981) shows that in Clarke's study, fewer warm-water species were taken by the wandering albatrosses than in either 1983 or 1984 . However, the data for 1983 are more similar to those of $1976 / 1977$ than the 1984 data.

The species composition and relative frequency of species showed some striking differences between the two years 1983 and 1984. Thirty-five species were recorded in 1983; forty-five were recorded in 1984. Of the ten species confined to 1984, one was Mesonychteuthis hamiltoni, a deep-living Antarctic species which grows to a large size (Rodhouse and Clarke, 1985) and which only occasionally occurs in the diet of albatrosses (Clarke and Prince, 1981; Clarke et al., 1981). The other nine species are all presumed to come from warmer water north of the SAF. Two species, Egea inermis and Megalocranchia sp. are thought to have tropical/sub-tropical distributions (Voss, $1974,1980)$. This suggests than in 1984 a more northerly cephalopod community was available to the birds, either because their foraging range (see Croxall et al., 1984) was extended, or because of a southerly incursion of water from the south Atlantic Ocean. It seems likely that the environmental conditions which caused the krill failure in the austral summer of 1983/1984 (Heywood et al., 1985) also influenced the cephalopod community available to wandering albatrosses in 1984.

Availability of warmer-water cephalopods in 1984 is reflected by the increase in the albatross diet of Illex sp. from 11 to $33 \%$ by numbers. The nearest known stock of Illex to South Georgia is I. argentinus, which occurs over the Patagonian shelf (Roper et al., 1984). It is possible that the increase in ommastrephids in the diet changed the energy content of the food delivered to the chicks, because those onychoteuthids which store ammonium as a buoyancy mechanism (Clarke et al., 1979) have lower energy contents than ommastrephids (Clarke et al., 1985). Thus, if it is assumed that Kondakovia longimana has the same energy content as Moroteuthis robusta and Illex sp. has the same energy content as Todarodes sagittatus, then the energy content of the cephalopod diet in 1984 would have increased by $9.6 \%$ as a result of increased consumption of $I$ lex sp.

Elsewhere, Offredo et al. (1985) have been able to demonstrate shifts in size-frequency peaks of squid beaks taken from the stomachs of Antarctic vertebrate predators during the austral summer. In the present study, those species numerous enough through time to be amenable to analysis showed no evidence of growth. The present study was conducted during the austral winter, and the data suggest that growth rate, at least in the commoner species, is much reduced during the period May to September.

Clarke et al. (1981) pointed out that several of the families of cephalopod consumed by wandering albatrosses were previously thought to be deep-living. Recent data on vertical distribution of squid, as sampled by nets in the Antarctic (Rodhouse and Clarke, 1985, 1986; Rodhouse, in press), confirm that for three species known to be consumed by wandering albatrosses the usual distribution of larger specimens is considerably deeper than the depths at which the birds could possibly capture their prey. Furthermore, in two species for which there is sufficient data, $\mathrm{Al}$ luroteuthis antarcticus and Galiteuthis glacialis, there is evidence of ontogenetic descent. Whilst we still maintain that seabirds probably consume the remains of cephalopods regurgitated by whales (Clarke et al., 1981), the question of whether other sources of cephalopods are available must be addressed. Given that ontogenetic descent occurs in several squid species, including some from the Antarctic, there is clearly a return towards the surface at some phase in the life cycle. Eggs may be laid at depth and float towards the surface, hatchlings may hatch at depth and migrate towards the surface, or adults may migrate towards the sur- 
face to mate and/or spawn. Given that many species of cephalopods are semelparous and die after spawning (see Boyle, 1983), if mating/spawning migrations towards the surface followed by mass mortalities do occur, then these aggregations would represent considerable, but sporadic, opportunities for surface-foraging seabirds. The adult size at reproduction of Antarctic cephalopods is not known, so the present data cannot support this hypothesis. However, it is notable that there is a relatively small size range of beaks from most cephalopod species in the regurgitations of wandering albatross chicks.

It has been proposed by Imber and Russ (1975) that wandering albatrosses feed mostly at night and detect cephalopod prey through their bioluminescence. We adhere to the view expressed by Clarke et al. (1981), that this is unlikely because the light organs of most species are screened in such a way as to be invisible from above (Young, 1977).

Acknowledgements. We thank J. P. Croxall and P. A. Prince for their advice and criticism, and P. G. Copestake, R. Lidstone-Scott, M. J. O'Connell, B. C. Osborne and S. P. C. Pickering, who made the collections of cephalopod beaks.

\section{Literature cited}

Boyle, P. R. (Ed.): Cephalopod life cycles, Vol. 1. 475 pp. London: Academic Press 1983

Clarke, A., M. R. Clarke, L. J. Holmes and T. D. Waters: Calorific values and elemental analysis of eleven species of oceanic squids (Mollusca: Cephalopoda). J. mar. biol. Ass. U.K. 65, 983-986 (1985)

Clarke, M. R.: Cephalopods in the diet of sperm whales of the southern hemisphere and their bearing on sperm whale biology. 'Discovery' Rep. 37, 1-324 (1980)

Clarke, M. R.: A handbook for the identification of cephalopod beaks, 273 pp. Oxford: Clarendon Press 1986

Clarke, M. R., J. P. Croxall and P. A. Prince: Cephalopod remains in the regurgitations of the wandering albatross Diomedea exulans L. at South Georgia. Br. Antarct. Surv. Bull. 54, 9-21 (1981)

Clarke, M. R., E. J. Denton and J. B. Gilpin-Brown: On the use of ammonium for buoyancy in squids. J. mar. biol. Ass. U.K. 59, $259-276(1979)$

Clarke, M. R. and P. Prince: Cephalopod remains in regurgitations of black-browed and grey-headed albatrosses at South Georgia. Br. Antarct. Surv. Bull. 54, 1-7 (1981)

Croxall, J. P., T. S. McCann, P. A. Prince and P. Rothery: Variation in reproductive performance of seabirds and seals at South Georgia 1976-1986 and its implication for Southern
Ocean monitoring studies. In: Antarctic Ocean and resources variability, Ed. by D. Sahrhage. Heidelberg/Berlin: SpringerVerlag (In press)

Croxall, J. P., C. Rickets and P. A. Prince: Impact of seabirds on marine resources, especially krill of south Georgia waters. In: Seabird energetics, pp 285-317. Ed. by G. Causey Whittow and Herman Rahn. New York: Plenum Publishing Corp. 1984

Fischer, W. and J. C. Hureau (Eds.): FAO species identification sheets for fishery purposes. Southern Ocean (Fishing areas 48, 58 and 88) (CCAMLR Convention Area), Vol. 1. $232 \mathrm{pp}$ Rome: F.A.O. 1985. (Prepared and published with the support of the Commission for the Conservation of Antarctic Living Marine Resources)

Heywood, R. B., I. Everson and J. Priddle: The absence of krill from the South Georgia zone, winter 1983. Deep-Sea Res. 32, $369-378(1985)$

Imber, M. J. and R. Russ: Some foods of the wandering albatross Diomedea exulans. Notornis 22, 27-36 (1975)

Matthews, L. H.: The birds of South Georgia. 'Discovery' Rep. 1, 561-592 (1929)

Nelder, J. A. and P. McCullagh: Generalized linear models, 261 pp. London: Chapman \& Hall 1983

Offredo, C., V. Ridoux and M. R. Clarke: Cephalopods in the diet of Emperor and Adelie penguins in Adelie Land, Antarctica. Mar. Biol. 86, 199-202 (1985)

Okutani, T. and M. R. Clarke: Identification key and species description for Antarctic squids. BIOMASS Handb. Ser. 21, 1-57 (1985)

Pielou, E. C.: The measurement of diversity in different types of biological collections. Theor. Biol. 13, 131-144 (1966)

Rodhouse, P.G.: Distribution of the neoteuthid squid $\mathrm{Al}$ luroteuthis antarcticus Odhner in the Atlantic sector of the Southern Ocean. (Malacologia) (In press)

Rodhouse, P. G. and M. R. Clarke: Growth and distribution of young Mesonychteuthis hamiltoni Robson: and Antarctic squid. Vie Mileu 35, 223-230 (1985)

Rodhouse, P. G. and M. R. Clarke: Distribution of the early-life phase of the Antarctic squid Galiteuthis glacialis in relation to the hydrology of the Southern Ocean in the sector $15^{\circ}$ to $30^{\circ} \mathrm{E}$. Mar. Biol. 91, 353--357 (1986)

Roper, C. F.E., M. J. Sweeney and C. E. Nauen: FAO species catalogue. Vol. 3. Cephalopods of the world. An annotated and illustrated catalogue of species of interest to fisheries. F.A.O. Fish. Synopses 125, 1-277 (1984)

Tickell, W. L. N.: The biology of the great albatrosses Diomedea exulans and Diomedea epomophora. Antarctic Res. Ser. 12, $1-55(1968)$

Voss, N. A.: Studies on the cephalopod family Cranchiidae. A redescription of Egea inermis Joubin, 1933. Bull. mar. Sci. 24, 939-956 (1974)

Voss, N. A.: A generic revision of the Cranchiidae (Cephalopoda: Oegopsida). Bull. mar. Sci. 30, 365-412 (1980)

Young, R. E.: Ventral bioluminescent countershading in midwater cephalopods. Symp. zool. Soc. Lond. 38, 161-190 (1977)

Date of final manuscript acceptance: May 22, 1987.

Communicated by J. Mauchline, Oban 